\title{
FORUM
}

\section{AND NOW FOR SOMETHING COMPLETELY DIFFERENT: ADDRESSING ASSUMPTIONS ABOUT MYTH}

Abstract: Many students in introductory myth classes assume that Greco-Roman myth is comprised of a canonical collection of well-known stories, and that those stories might be entertaining but ultimately have little relevance to the modern world. This essay explores ways to address these assumptions and help students to understand the complexity of myth, how it was used to explore social issues, and how it can still be relevant today. I also discuss a lecture that explores modern attitudes toward representing the divine in song, film and literature, and then compares our attitudes to those of the Greeks.

any students who enroll in the introductory mythology course at the
University of Wisconsin in Madison bring with them a good deal of
experience. In any given semester a large number of students, if not a majority, have already read myths in some form as a child or adolescent (now more than ever since the publication of the Percy Jackson series), seen mythological stories retold in movies, studied myth as literature in high school, or had some combination of these and other experiences. Many students, therefore, begin their first college-level myth course already familiar with the important narratives and knowing a good deal about the major gods and heroes. And they are, on the whole, eager to learn more.

Despite their background, these same students, as well as those with little or no experience, are usually unaware of the assumptions about ancient literature, culture, and religion that they also bring to class and that form the lens through which they view myth. If left unchallenged, these assumptions can prevent students from moving beyond a superficial understanding of the texts they read.

One fundamental assumption has to do with our sources. Because students have read books of collected myths and are familiar with or participate in religious traditions where sacred scripture plays a central role, they often assume, quite naturally, that there also exists a canon of mythological stories or even standard texts passed down from antiquity that we can still read today. They are surprised when we tell them, as Powell has put it, that, "there's no such thing as 
classical myth; it really doesn't exist." ${ }^{1}$ Exaggerated somewhat for emphasis, this sort of statement is meant to be startling to students on the first day of a course billed as "Classical Myth," alerting them that the Greeks and Romans did not write myths per se, but rather included mythological elements in a wide range of oral and written literature, over a broad expanse of time, and in various cultural settings. Students quickly learn that they must be investigators, not simply readers, in order to come to grips with Greco-Roman myth.

Authors of college-level myth textbooks are aware of students' assumptions and know that, as a consequence, their collections could be seen as presenting authoritative versions of myths and could therefore be misleading. Although they are careful to point out that they have assembled their stories selectively and have knit them together from several sources, they usually focus not so much on the variations in the myths as on the underlying themes that give them coherence or that connect Greco-Roman mythology to Near Eastern and other traditions. Directing the students' attention to the variations, however, opens the door to examining other misconceptions that can also obscure the complexity of classical myth and hinder the development of good interpretive skills. For instance, just as students might assume an orderly process for the creation and transmission of the texts, they might also imagine that the gods they encounter will be theologically well defined and the heroes consistently presented. However, having been made aware of the potential for variation and inconsistency in the stories, they can be encouraged to read the originals for themselves and to look for significance in, rather than be frustrated by, the variation that they encounter.

I have found that a good starting point for this sort of exercise is comparing the Odysseus of the Odyssey to the one who appears in the Philoctetes, and probing Sophocles' morally challenging interpretation of the Ithacan's lying ways. Working through a straightforward case such as this helps students to make more subtle analyses of, for example, the nature of Zeus in Homer and Hesiod, or the differences between the Aphrodite who is made to fall in love with Anchises to her great shame (Hymn to Aphrodite) and the Venus who eagerly pursues Adonis (Ovid Met. 10). Given some direction and a little background information, students are able to consider the cultural, literary, and even philosophical influences that affected the poets' interpretation of myth during all periods. And so, when they come to Ovid's creation story (Met.1) and read about the "god who is nature" bringing order to conflicting forces, they are prepared to see not a

${ }^{1}$ Brooks (2011). 
contradiction of Hesiod's Theogony, where the first deities arise spontaneously out of a void, but an old story in a new form, influenced by developments in scientific thinking and a change in venue from Archaic Greece to Augustan Rome.

In order to assist students in their investigation of myth, I arrange my syllabus chronologically, first reading Archaic Greek poetry (Homer, Hesiod, and the long Homeric Hymns), then turning to the Classical period, with a focus on tragedy, and finally to Rome and Ovid. The main emphasis of our study of the Classical period is the tragedians' use of myth to explore contemporary problems. This is nothing new to scholars of Greek drama, but it can be surprising to students who expect myths to be the old-fashioned tales, often with simple morals, that they read in their youth. We discuss, for example, Euripides' Phoenissae in the context of the Peloponnesian War and political unrest in Athens, and Sophocles' Trachiniae with an eye towards Deianira's feelings of insecurity and rejection when faced with a younger rival for Heracles' affection. Once students come to understand how myths were used to illuminate and explore problems of Greek society, they very quickly realize that these same stories can also be useful for coming to terms with modern problems. For instance, a few years ago, when the country was debating the use of torture to combat terrorism, my students could see that Neoptolemus' moral dilemma in the Philoctetes neatly set out the conflicting interests of our own debate and how the lack of a proper conclusion to Neoptolemus' internal struggle in the play underscored the difficulty in reconciling those interests in the real world. This sort of moral insight has been the impetus for revivals of several tragedies, including the Philoctetes, during the difficult years of the past decade, and so it seems particularly important not to pass over the contemporary relevance of such a myth when presenting it to the modern student. ${ }^{2}$

The value of reading classical myth for understanding both ancient and modern society leads to the last point I would like to consider. When focusing on myths as stories, we can very easily miss the fact that the Greeks regularly depicted their gods in both flattering and unflattering situations. (I leave Ovid and other Romans out of this discussion, since their mythological literature was based on Greek models.) Zeus, for example, is sometimes the revered "father of gods and men" (as in Hesiod) and other times the great philanderer (passim in Greek mythology); in the Iliad Hephaestus solemnly crafts divine armor for

${ }^{2}$ See, for example, Healy (2009). 
Achilles, while in the Odyssey he catches his wife, Aphrodite, in the act of adultery but receives no sympathy, only laughter, from his fellow gods; and Dionysus in Euripides' Bacchae destroys Pentheus for his lack of respect, but in Aristophanes' Frogs he is a buffoon on stage at his own festival. For Classicists and students alike, who have been reading Greek myths for many years, this sort of depiction seems natural, but actually it is quite remarkable, especially in comparison with our own society's attitudes about representations of deities.

In order to draw the students' attention to the Greeks' tolerance in this regard and to spend some time exploring our own, modern attitudes, I devote one lecture late in the semester to discussing the reception of modern music, film, and literature that refer to or represent the deity in unconventional ways. Both the title and the theme of the lecture are "God as Character." I begin by playing the Beach Boys' song, "God Only Knows." With its harmonizing vocals and sentimental lyrics ("God only knows where I'd be without you," repeated several dozen times), this song is entirely unobjectionable to the modern undergraduate, almost to the point of being embarrassing. But when it was recorded in 1966, there was real concern that it might cause offense. According to the lyricist Tony Asher, he and Brian Wilson, the composer, "had lengthy conversations during the writing of 'God Only Knows,' because unless you were Kate Smith and you were singing 'God Bless America,' no one thought you could say 'God' in a song. No one had done it, and Brian didn't want to be the first person to try it." In the early twenty-first century, this fear seems absurd, but reading the lyrics to "God Bless America" helps to clarify what Asher and Wilson were worried about:

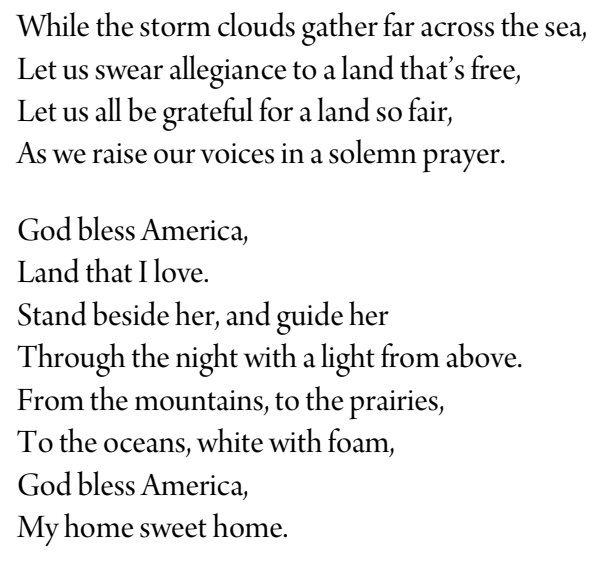

${ }^{3}$ Granata (2003) 100-1. 
Irving Berlin, who composed both the music and the lyrics, appears not to have conceived of "God Bless America" simply as a song, but more as a secular hymn, even making clear at the end of the first stanza that the deity's name would be invoked in the context of prayer. Times change, of course. These days, Berlin's context-setting first stanza is rarely sung as part of "God Bless America." (I admit that I had forgotten the words, if I ever knew them, until I looked them up while writing this lecture.) As for the Beach Boys, by 2006 their "God Only Knows" was considered inoffensive enough that Sam's Club could use it as background music in a television commercial. ${ }^{4}$ The point I make to the students is that in modern society, despite shifting standards and differing opinions, we nonetheless think very carefully about how the deity is depicted in art and literature.

Having encouraged the students to reflect on the mention of God in a song, I move on to another example, from Monty Python's 1979 film Life of Brian, which deals with more controversial subject matter but which over time experienced a drastic change in reception. I show the students the final scene from the film, which is a parody of the crucifixion of Christ as presented in the Gospels and in large-scale Hollywood movies. This scene is often considered one of the most offensive in the film, and I believe that students, even if they are not offended (although some may be), can at least appreciate how this version of the crucifixion could be regarded as inappropriate or lacking in taste.

After showing the clip, I summarize some of the immediate reactions to the film, which are documented in news articles from the Associated Press. For example, three organizations of orthodox Jewish rabbis claimed that "the movie insulted Jews and could cause violence;" " the Roman Catholic Archdiocese of New York condemned it as "bigoted, blasphemous and a crime;" ${ }^{6}$ the district attorney in Baton Rouge, LA, persuaded a theater manager to stop showing it, calling the movie "filthy and crude;" 7 and in Columbia, SC, it "opened and closed on the same day" because a Presbyterian minister contacted Nancy Thurmond, who alerted her husband, Senator Strom Thurmond, who in turn called an attorney for General Cinema to inform him of the "potentially explosive situation

\footnotetext{
${ }^{4}$ The song was also used during the opening credits for the first three seasons of the $\mathrm{HBO}$ series Big Love

${ }^{5}$ Associated Press (August 26, 1979).

${ }^{6}$ Associated Press (August 30, 1979).

${ }^{7}$ Associated Press (October 14, 1979).
} 
in Columbia." ${ }^{8}$ Articles also document a backlash against the backlash: a judge in Valdosta, GA, issued a temporary restraining order against the film, but then vacated the order the next day, ${ }^{9}$ and a theater owner in Laconia, $\mathrm{NH}$, canceled a scheduled showing of the movie after receiving calls of protest, only to find that he received even more calls criticizing the cancellation. ${ }^{10}$ In addition to questioning the censorship of the movie, some also began to reevaluate its content. According to the Cornell Chronicle John Cleese, one of the movie's creators and stars, gave a talk at Cornell University entitled, "What is Religion? Musings on the 'Life of Brian." "11 That is to say, he was treated as an authority on religion partly for his role in making the film. Similarly, the BBC reported that an Anglican church in Newcastle was planning to screen the film and even to encourage the audience to sing along with the songs. ${ }^{12}$ According to the Rev. Jonathan Adams, "Jesus of Nazareth is not some sort of hot house plant that we need to protect from criticism and scrutiny." In addition to enjoying the film, the organizers intended to take seriously the questions it raises about Christian religious practices.

"God Only Knows" and Life of Brian are useful introductions to the problem of God as character because their messages are presented in popular music and film, forms that students are used to interpreting, and because they make reference to the deity with developing complexity. Whereas the Beach Boys presented an innocent (if sappy) message and were worried about causing offense unintentionally, the Monty Python group was being deliberately satirical, and in the end they generated controversy that led to serious discussions about censorship and religion. Nonetheless, they presented the life and crucifixion of a fictitious character, and so they parodied the Gospel story without manipulating the words and actions of Christ directly.

After thinking about these two examples, the students are ready to consider a more complicated literary text, The Last Temptation of Christ by the Greek author Nikos Kazantzakis. Kazantzakis, in contrast to the Pythons, attempted something akin to Aristophanes' Frogs by making Christ the central character in his novel

${ }^{8}$ Associated Press (October 20, 1979).

${ }^{9}$ Associated Press (October 30, 1979).

${ }^{10}$ Associated Press (November 3, 1979).

${ }^{11}$ Moss (2004).

${ }^{12}$ BBC News (February 23, 2007). 
and using him to explore ideas that went beyond his sources. And because his sources were sacred texts, the publication of the book stirred a strong reaction. ${ }^{13}$

Christian theologians have long insisted on the dual nature of Christ, believing him fully divine and fully human at the same time. Kazantzakis explores Christ's humanity in a vivid narrative that at the time of publication made many readers uncomfortable. I show the students how Kazantzakis took inspiration from Gospel passages where Christ was tested by the devil (e.g. Mat. 4.1-11) and dreaded his impending torture and death (e.g. Mat. 26.39) in order to weave together a greater temptation, where the devil offers him the chance at a normal, human life if he will decline to go through with his crucifixion. But Kazantzakis, as I mentioned, went well beyond his sources, and so I also discuss how he relied on his own experience and imagination to enrich his character and probe more deeply into Christ's humanity than the Gospels do. He explains this himself in a letter written just as the book was being published: ${ }^{14}$

Some were shocked that Christ had temptations. But while I was writing this book, I felt what Christ felt. I became Christ. And I knew definitely that great temptations, extremely enchanting and often legitimate ones, came to hinder him on his road to Golgotha. But how could the theologians know all this?

After reading this excerpt, I point out to the students that Kazantzakis was not satirizing the Gospels, but he was claiming through his fictional narrative to have presented a more detailed and even a more accurate character sketch than was found in the New Testament or explained by theologians.

The response, however, was condemnation, and eventually excommunication. Turning again to Kazantzakis' own words: ${ }^{15}$

And the [Greek] Orthodox Church of America convened and damned the Last Temptation as extremely indecent, atheistic, and treasonable, after

\footnotetext{
${ }^{13}$ This is not to say that The Last Temptation was universally condemned. The students prepare for this lecture by reading Iannone (1996), an article that considers the value of both Kazantzakis' novel and Martin Scorsese's film adaptation from a religious perspective.

${ }^{14}$ Kazantzakis (1983) 515-16; letter dated November 27, 1952. The book was published abroad in various translations beginning in 1951 and was first published in Greek in 1955. The first English edition appeared in 1960. I have taken bibliographic information from www.kazantzakismuseum.gr.

${ }^{15}$ Kazantzakis (1983) 523-4; letter dated May 14, 1954
} 
admitting that they hadn't read it and based their case on the articles in [the Greek newspaper] Estia.

I remind the students that this controversy did not arise because Kazantzakis changed the outcome of the story. His Christ is tempted and must struggle to resist, but he ultimately rejects the devil and accepts crucifixion. Even so, many Christians were unwilling to follow Kazantzakis as he supplemented the Gospel narratives and orthodox theology in order to push beyond the generally accepted notions of Christ's humanity.

Although the modern works I examine with my students have become accepted and even mainstream today, I attempt to demonstrate that they did not achieve that status without controversy and debate. I also point out that despite changing times and attitudes, our culture still takes a cautious approach, using as one example the fact that the major television networks, our largest national stage, still prefer traditional treatments of God as character. ${ }^{16}$ This sets us quite apart from the Greeks. In order to mark the distinction, I ask the students to consider the scene from Aristophanes' Frogs where Dionysus gets into Charon's boat to cross over to Hades. Here the deity provides comic relief, being verbally abused by Charon, proving inept as a rower, passing gas, and being drawn into - and losing - a croaking contest with the frogs. Aristophanes' purpose in the play was not to mock the god, but to use his character to parody mythological stories and to comment on the state of the Athenian theater. Athenians of the Classical period could tolerate and even enjoy the bumbling Dionysus, apparently without feeling offense or accusing Aristophanes of sacrilege.

My aim in this lecture is to highlight the Athenians' acceptance in this regard and to create greater awareness of own society's values and biases. This awareness can then spark discussion of related questions, such as how we conceive of piety differently than the Greeks, how religious and secular texts interact, and who (in ancient or modern society) has the authority to enforce what we in the television era call "standards and practices." These are larger questions, not directly related to myths as stories, but they naturally arise when students are encouraged to read myths in their literary and cultural contexts. As with the readings of tragedy mentioned above, these questions help students to realize that Greco-Roman myth has been and continues to be an important tool for defining and exploring important political, social, and religious issues.

\footnotetext{
${ }^{16}$ See, for example, the ABC network's tradition of showing the 1956 film The Ten Commandments on Easter weekend.
} 
Thinking about these issues also helps to break down what is perhaps the most ingrained assumption among students, especially those in the sciences and engineering: that mythology, and ancient literature in general, might be entertaining but it has little relevance for the modern world. As the students are drawn into the investigation, and not simply the reading, of myth, they come to understand that the enduring value of the stories is more complex and more relevant to their own lives than they might initially have assumed.

JEFFREY BENEKER

University of Wisconsin, jbeneker@wisc.edu

\section{WORKS CITED}

Brooks, Susannah. 2011. "Eighty Years and Thousands of Stories Endure in Classical Myth Course." University of Wisconsin News Service, February 22, 2011: www.news.wisc.edu/18925.

Granata, Charles L. 2003. Wouldn't It Be Nice: Brian Wilson and the Making of the Beach Boys' Pet Sounds. Chicago.

Healy, Patrick. 2009. "The Anguish of War for Today's Soldiers, Explored by Sophocles." New York Times, November 12, 2009: C1.

Iannone, Carol. 1996. "The Last Temptation Reconsidered." First Things 60: 50-4.

Kazantzakis, Helen. 1983. Nikos Kazantzakis: A Biography Based on His Letters. Berkeley. Translated by A. Mims from the 1968 original French edition.

Moss, Simeon. 2004. "John Cleese offers insights, 'expertise' on religion in Oct. 22 lecture." Cornell Chronicle, October 28, 2004. 